\title{
Stunted policy support
}

Energy policy is widely debated, with regards to climate change, alternative energy use and responsibility for policy. Research now highlights the role of citizens in public debates about energy and how it can be swayed.

\section{James N. Druckman}

C hanges to the energy system depend on what re-election-oriented politicians are willing to do - they would not pass laws that are not supported by their constituents - and on what consumers in the marketplace are willing to accept: will they pay for hybrid cars or energy-efficient light bulbs? Therefore, when it comes to energy, the role of citizens is critical. Despite the influence of public opinion on the feasibility of any new energy policy, the study of the role of public opinion remains in an infancy phase. What we do know, however, is that public opinion in general and specifically in the case of energy policies depends at least in part on how the debate is 'framed' by elites. Writing in Global Environmental Change, Michaël Aklin and Johannes Urpelainen ${ }^{1}$ show that, in the context of clean energy policy, counter messages undermine the original ones and have little effect on public support.

Framing refers to the placing of emphasis on distinct dimensions of the issue under consideration (for a discussion with regard to nuclear energy, see ref. 2). For example, if elite actors such as policy advocates, the media, or politicians frame nuclear energy as a cost-efficient, environmentally sound alternative, the public may increase its support for usage. Yet if the frame instead emphasizes health risks, support is likely to drop. Framing effects of this sort have been shown to occur across social and political issues ranging from campaign finance (free speech versus special interests), abortion (rights of mother or rights of unborn child?), gun control (right to bear arms or public safety?), affirmative action (reverse discrimination or remedial action?), welfare policy (humanitarianism or overspending?) and elections (economy or foreign affairs?) ${ }^{3}$. There is no doubt that a dominant frame can shape opinion with concomitant policy implications, as mentioned. This reality has been recognized not only by social scientists but also by the policy community ${ }^{4}$.

Aklin and Urpelainen ${ }^{1}$ have produced a new and insightful analysis showing how alternative frames influence opinions about cleaner energy. They do so by means of a survey experiment using a representative

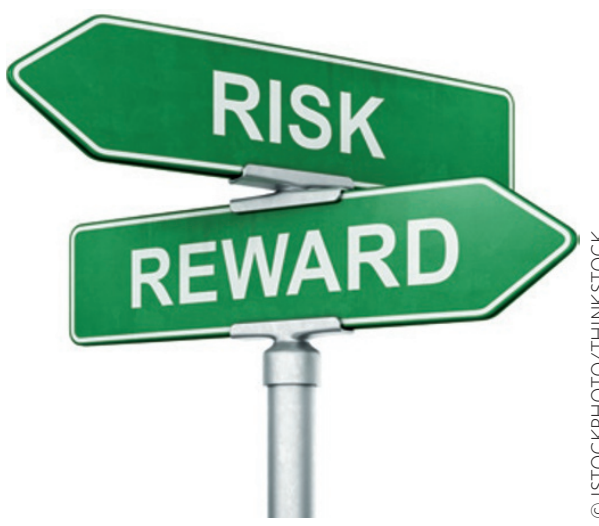

sample of citizens in the USA. What is really interesting about the article is the incorporation of one of the democratic aspects of politics: competition. That is, when one side attempts to frame an issue one way, the other side often counter-frames with an alternative outlook. Even so, few studies have explored what happens when such competing frames occur ${ }^{5,6}$. The work by Aklin and Urpelainen is one of the first to explore competing frames when it comes to energy politics, with a focus on polices to promote clean energy (that is, wind and solar power). Consistent with the few previous studies on other topics such as affirmative action, hate group speech and urban sprawl, the researchers find that opposite and equally strong frames cancel out, therefore appealing to the economic or national security benefits of clean energy does nothing to increase support when countered by the opposing frame - economic or national security risks. The analysis is also new in that it considers each dimension (economics and national security) in both positive and negative terms. This represents a significant contribution to the public opinion literature that tends to highlight only alternative dimensions (for example, economic benefits versus national security risks). The authors ${ }^{1}$ also show that single frames can matter, although curiously, one of the single negative frames (specifically, the negative economic frame) has scant effect on public support. This is surprising given that cognitive processes generally weigh more negative frames, such as economic costs, than positive ones (economic benefits).
The authors clearly recognize the need for more work, but they do not give details about specific aspects such as those highlighted here. First, few issues are as politicized as energy. Thus, it is critical that future work includes politicization by incorporating alternative partisan views ${ }^{7}$. Second, will the effects found last over time - do people change their views when exposed to a specific frame, such as in the study by Aklin and Urpelainen, then stick to those views? According to motivated reasoning theory, once people become entrenched in a view, they counter-argue an alternative and this process can be studied only over time ${ }^{8}$. Aklin and Urpelainen offer counter-frames simultaneously but the reality of politics is that frames and counter-frames occur over time - is there an advantage to coming first or second? Third, what happens if scientific evidence is introduced on the benefits or costs of new energy sources? Do people discount evidence inconsistent with a frame even if it is from a credible source such as the National Academy of Sciences, or can this make one frame more effective than another?

In sum, the work by Aklin and Urpelainen $^{1}$ is an extremely important step forward in the research on the public and energy policy. It shows that competing simultaneous frames stunt support for new energy initiatives. As such, it deeply enhances our understanding and at the same time sets an agenda for critical future work.

James N. Druckman is in the Department of Political Science, Northwestern University, Scott Hall, 601 University Place, Evanston, Illinois 60208, USA.

e-mail:druckman@northwestern.edu

\footnotetext{
References

1. Aklin, M. \& Urpelainen, J. Global Environ. Change http://dx.doi.org/10.1016/j.gloenvcha.2013.03.007 (2013). 2. Gamson, W. A. \& Modigliani, A. Am. J. Sociol. 95, 1-37 (1989). 3. Schaffner, B. F. \& Sellers, P. J. (eds) Winning with Words: The Origins and Impact of Framing (Routledge, 2010).

4. Nisbet, M. C. \& Mooney, C. Science 316, 56 (2007).

5. Sniderman, P. M. \& Theriault, S. M. in Studies in Public Opinion (eds Saris, W. E. \& Sniderman, P. M.) 133-166 (Princeton Univ. Press, 2004)

6. Hansen, K. M. Scand. Polit. Stud. 30, 377-396 (2007).

7. Slothuus, R. Polit. Commun. 27, 158-177 (2010).

8. Lodge, M. \& Taber, C. in Elements of Reason: Cognition, Choice, and the Bounds of Rationality (eds Lupia, A., McCubbins, M. D. \& Popkin, S. L.) 183-213 (Cambridge Univ. Press, 2000).
} 